UDC $021.61(100): 070: 654.195: 78$

DOI https://doi.org/10.24919/2308-4863/44-3-4

Oleg SYNIEOKYI,

orcid.org/0000-0002-1419-4964

Doctor of Social Communications,

Professor at the Department of Philology and Publishing

Mykhailo Ostrohradskyi National University

(Kremenchuk, Poltava region, Ukraine)vinyl-doc@email.ua

\title{
'WE ALL CAME OUT TO MONTREUX...' (A PHONODOCUMENTARY STUDY ON THE SWISS ROCK MUSIC)
}

The problem of studying the archival musical heritage requires a new scientific understanding. It is acknowledged that many interesting iconic music projects and entire regional schools, one of which is Swiss, have been left out of the research interest. Hence, the article presents a phono-documentary analysis of the heritage of Swiss rock music. The urgency of the topic of the publication is due to the lack of scientific papers on the history of Swiss rock music in the background. The aim of the work is the scientific substantiation of social and communication principles of development of the Swiss school of rock music. The subject of research is the peculiarities of the development of Swiss Rock music in terms of sound and documentary communication. The empirical basis of the study consists of archival sources, including 10,000 vinyl records and 8,000 CDs, catalogs of record companies, periodicals, more than 2,000 sites, blogs and online resources, "Swiss Pop \& Rock Anthology», as well as some unpublished materials. Based on the discographic analysis of musical sound documents and other sources, the chronological picture of Swiss rock music was reconstructed for the first time. Attention is focused on the study of communicative conditions of functioning and the causes of repertoire-genre transformations. Key episodes in the history of Swiss Rock music are combined by lines of communication through the prism of the stories of individual music projects in the context of the overall history of world popular music. The methodological basis is the basic provisions of the general theory of social communications. Methodological support was based on the use of general scientific and special methods, which are determined by the purpose and objectives of the study. The author's special contribution is to clarify the chronology of a number of events. The author concludes that despite the presence of four official languages in Switzerland - French, German, Italian and Retoromansh, communication in the field of rock music is mainly English. This is because of the special type of culture in this country called «Music for Export».

Key words: Album, Records, Band, Discography, Sound Recording, Music, Rock, Single, Switzerland.

олег СИНСОКИЙ, orcid.org/0000-0002-1419-4964

доктор наук з соиіальних комунікацій, доцент, професор кафедри філологї та видавничої справи Національнјиј університете імені Михайла Остроградського (Кременчук, Полтавська область, Украӥна) vinyl-doc@email.ua

\section{«МИ ВСІ ПРИЇХАЛИ ДО МОНТРЮ...»: ФОНОДОКУМЕНТНЕ ДОСЛІДЖЕННЯ ШВЕЙЦАРСЬКОЇ РОК-МУЗИКИ}

\begin{abstract}
Проблема вивчення архівної музичної спадщчни вимагає нового наукового розуміння. Визнається, щяо поза увагою дослідницького інтересу залишилося досить багато як иікавих $і$ знакових музичних проєктів, так $і$ ицілих регіональних шкіл, однією з яких є швейцарська. У статті викладено фонодокументний аналіз спадщини швейияарської рок-музики. Актуальність теми публікаџї зумовлена відсутністю наукових прачь, присвячених історії швейиарської рок-музики у фонодокументному відображенні. Метою роботи є наукове обтрунтування сочіальнокомунікаційних засад розвитку швейцарської школи рок-музики. Предмет дослідження - особливості розвитку швейиарської рок-музики із погляду на фонодокументну комунікачію. Емпіричну базу становлять архівні джерела, зокрема 10 тисяч грамплатівок і 8 тисяч CD, каталоги фірм грамзапису, періодична преса, більше 2 тисяч сайтів, блогів і мережевих ресурсів, Swiss Pop \& Rock Anthology, а також окремі неопубліковані матеріали. Cпираючись на дискографічний аналіз музичних фонодокументів та інших джерел, уперше проведено реконструкцію хронологічної картини швейцарської рок-музики. Увагу зосереджено на вивченні комунікативних умов і причин репертуарно-жанрових трансформацій у звукозаписувальній системі. Ключові епізоди історії швейцарської рокмузики поєднуються лініями комунікації через призму історій окремих музчиних проєктів у контексті загальної історії світової популярної музики. Методологічною основою є базові положення загальної теорії соиіальних комунікацій. Методологічне забезпечення трунтувалося на використанні загальнонаукових і спеціальних методів, що визначаються метою $і$ завданнями дослідження. Особливий внесок автора полягає в уточненні хронологї низки подій. Автор робить висновок про те, щзо, незважаючи на наявність у Швейцарії чотирьох офіційних мов (франиузької, німецької, італійської та ретороманської), комунікація у сфері рок-музики відбувається переважно англійською. Це пояснюється особливим типом культури цуієї країни під назвою «Музика на експорт».
\end{abstract}

Ключові слова: альбом, грамплатівки, група, дискографія, звукозапис, музика, рок, сингл, Швейцарія. 
After all, Rock music as a unique social and communicative phenomenon has influenced and continues to influence the development of society. In Rock culture, the Swiss Confederation is famous primarily for the city of Montreux, located on the shores of Geneva Lake, with many recording studios, including the famous Mountain Studios, which has hosted many iconic bands. It was in Montreux that the monumental hard rock hit of all times and people were born with the best heavy guitar riff in the Universe. As we know, sitting at the window of the Grand Hotel, Ian Gillan, watching the casino burning during the Frank Zappa concert and the smoke creeping over the surface of the lake, sketched the legendary text for 'Smoke on the Water'. At this time, the 'Machine Head' album (1972) was being recorded at the Rolling Stones traveling studio...

Among the numerous Swiss bands, three are best known: the heavy metal KROKUS, the electronic duo YELLO and the national heroes of the melodic hard rock GOTTHARD. And, nevertheless, this 'triumvirate' does not exhaust the diversity of the picture of Swiss popular and progressive music, which, despite the German, French, Italian and other ethnic influences, has a pronounced cultural identity. Next, let us summarize the most interesting of the rare names of progressive rock Swiss bottling.

The culturological nature of Rock Music as a social and communicative phenomenon has been repeatedly the subject of scientific research. In general, musical art in the system of mass communications was the subject of scientific analysis. The scientific achievements of Ukrainian and foreign researchers of the theory of social communications: M. Butyrina, I. Davydova, N. Kushnarenko, A. Solyanyk, J. Trout, W. Weaver, L. Filipova, Y. Finkler, K. Shannon, etc., which contribute to the general theoretical understanding of the objective processes of formation, development, functioning and systemic transformations of musical sound documents as a musical-audio component of the social-communicative reality of the second half of the XX century. It is necessary to name such foreign researchers as J. Boyd, R. Wise, H. McElam, J. Dawson, R. Coleman, K. Escott, J. Collins, K. Gardner, J. von Hoele, D. Hirschberg, C. Gillette, $\mathrm{N}$. Toshes, whose works relate to the historical origins of the creation and development of world music. Based on the discographic analysis of musical sound documents and other sources, for the first time to build a true scientific essay on the history of Swiss Rock music.

Music journalist, collector, and curator Samuel Mumenthaler describes the development of rock music in Switzerland chronologically and very precisely, but without getting lost in the details. Roland Fischbacher, Director of the Visual Communications program at the Bern School for the Arts, and Robert Lzicar, Design researcher and designer, discuss the evolution of the visual appearance of rock culture from its beginnings to the present day [Lurker Grand, 2015].

Swiss Rock and Roll began in 1957 when HULA HAWAIIANS brought rockabilly to Bern. And within a few years, the French-speaking sector of the Swiss youth playing music was completely dominated by French stars such as Johnny Hallyday. The first local stars were Larry Greco, Tony Rank (Jean Roulet), Pichi (Roger Bollier), Chris Lange. A few years later, every Swiss city had its own response to THE SHADOWS guitarist Hank Marvin. In Zurich it was a man named Walty Anselmo, in Basel it was Peter Brugger... But the big horn-rimmed glasses and the hairstyle were not the only deciding factors. In the early 1960s, Brugger was considered a highly experienced guitarist. We can say that he became one of the real pioneers of Swiss Rock: Gil Rocky \& LES ROCKYS, THE BLIZZARDS, LES SORCIERS, LES MODESTES, GLOBEMASTERS, THE CANNON BALLS, THE SEVENS, THE RED DEVILS, POLO'S PEOPLE, THE MORLOCKS, THE BLACK BIRDS, THE TEENAGERS, ATTACKS, THE CHAPS, THE LIGHTSTONES and other young artists. Some bands were exclusively instrumental (LES SORCIERS, LES RELAX...), others sang in French (LES AIGLONS, LES FAUXFRĖRES...), some in English (THE DYNAMITES, THE SHEAPES, THE WILD GENTLEMEN...), some in Italian (THE NIGHT BIRDS...), the fifth - in German, but the majority, stubbornly imitating THE BEATLES' vocal harmonies, tried to include songs in several languages into the repertoire. There was even a Swiss' SKORPION (as we remember, the neighbors in Germany and Hungary had enough 'scorpions' then), led by Jürg Anliker, who recorded the only single 'Dreh Dich Um' (1974) in German. This is how the regional phenomenon 'Swiss Beat' (or 'Berner Rock') gradually emerged, which reached its peak in development with the release of 'Heavenly Club' album (1968) LES SAUTERELLES. This garage group was founded in 1962 by Toni Vescoli, François Garzoni and Tony Quero.

One of the first progressive albums by young Swiss musicians was 'Walpurgis' (1969) with Psychedelia, Blues, Kraut Rock and classical elements, created by THE SHIVER (Mario Conza - bass guitar, flute, vocals; Roger Maurer - drums, vocals; Dany Rühle lead guitar, harmonica, vocals; Jelly Postorini - organ, piano; Peter Robinson-lead vocals). The author of the album cover is the Swiss surrealist artist Hans Rudolf 
Giger, whom many fans of fantastic cinema know him from the design of the cult film 'Alien' - a successful combination of 'horror' and space adventures brought the artist an Oscar in $1980 \ldots$ In the spring of 1969, two former members of EGG \& BACON, lead guitarist Danny Andrey and bassist Teddy Riedo formed a new band, ERTLIF, which included English vocalist Richard John Rusinski, organist James Mosberger and drummer Hans-Peter 'Bolle' Börlin. This project, dominated by mellotron, synthesizer, keyboards and guitar delights, essentially became the first progressive rock group in Switzerland. The excellent skill of the musicians who released their only album in 1972 made ERTLIF the pride of the country. However, in 1978, the group was disbanded. In 1993 ERTLIF was reformed and in 2001 the CD 'Illusions' was released. In March 2018, Rusinski died and the ERTLIF project was finally closed.

In the 1970s, Progressive Rock was played by many promising budget Swiss bands, of which one managed to mark themselves with giant discs (CARDEILHAC, EXIT, HAND, ISLAND, INFRA STEFF'S RED DEVIL BAND, McCHURCH SOUNDROOM, PACIFIC SOUND, PLAMP, RUMPELSTILZ, SOPHIE'S DREAM, SPOT, TEE MAC UNITED, FLAME DREAM, METHUSALEM, SKIBBEREEN, LISE SCHLATT, AFTER SHAVE, VIKING INVASION...), while others were able to release one or two singles each (DESDEMONA, HENRI, SPACE IN TIME, TURNING WHEELS, TOTHER SUNDAY, JOINT...). I would like to especially highlight MAINHORSE - the first group of the famous Swiss keyboardist Patrick Moraz (REFUGEE, YES, THE MOODY BLUES...) and the PYRANHA group, which recorded two unique French-language albums, which combine Space Rock, Hammond progressive, Psychedelia and Jazz Fusion.

BRIANTICKET is considered by many to be the pioneers of early European psychedelic and space music. In the late $1960 \mathrm{~s}$, this group was formed in Switzerland by Belgian-born keyboardist and arranger Joel Vandroogenbroeck. He studied classical piano and then went to jazz school, at the age of 15 he received the Art Tatum award for the youngest jazz pianist. But soon he was carried away by new strange sounds coming from kraut rockers AMON DUUL II, CAN and TANGERINE DREAM, and decided to create his own 'space band'. In addition to him, the original line-up includes guitarist Ron Bryer and drummer Wolfgang Paap. The trinity was joined by bassist Werni Fröhlich. With this line-up, they recorded their debut album 'Cottonwoodhill' (1971), which immediately sparked controversy over its association with psychedelic drugs. The record was sold in an envelope with a warning that 'you must listen to this tape only once a day, otherwise your brain could be destroyed'. All this led to the fact that the album was banned in several countries, including the United States. Since then, BRIANTICKET's reputation as a group of experimentalists at the forefront of underground and avant-garde music has solidified. After the death of Brayer, Joel moved to Italy and there he assembled a new line-up of a group of Swiss musicians: Barney Palm - drums, percussion and all the strange sounds; Martin Sache) - bass, flute; Rolf Hug - guitars, vocals; Jane Free - backing vocals, percussion, tambourine and whistle. In 1972, BRIANTICKET's second album was released under the name 'Psychonaut'. This disc featured heavy psychedelia mixed with cosmic sound. The third album 'Celestial Ocean' (1973), recorded by Joel with the help of vocalist Carole Muriel and drummer Barney Palm, recounted how Egyptian kings traveled through space and time from desert lands to pyramids. This disc brought the group the greatest recognition. Wandroogenbrock then went on to explore new sonic galaxies with two more albums, 'Adventure' (1980) and 'Voyage' (1982). The 'Alchemic Universe' (CD, 2000) opened a series of re-editions of archival rarities from the BRIANTICKET legacy...

In the Swiss Rock history, NAUTILUS remains one of the underestimated masterpiece progressive projects. In 1974, bassist Urs Lerch, vocalist and guitarist Christian Bauer, keyboardist Ralph Stucki formed a band whose landmarks were psychedelic symphonic rock inspired by cosmic harmonies. In the fall of 1977, the Sunrise studio recorded the soundtrack for the debut album '20,000 Miles under the Sea' (1978). In 1979 the band was joined by guitarist Dieter Ruf and drummer Peter Fibich, who brought new musical ideas. In 1980, the second album 'Space Storm' was released, for which 9 tracks were recorded, but only eight were on the disc. In 2014, the missing title track - 'Space Storm' - was found in the archives and published on the $\mathrm{CD}$ 'The Legend'. Christian Bauer passed away in December 2015. And while NAUTILUS' recordings have touches of early URIAH HEEP, BLACK SABBATH, IRON BUTTERFLY, Jon Lord's solo work and some harmonic quotes from ELO plus WISHBONE ASH's vocal intonations, they managed to become a coherent line-up that differs from other symphonic rock bands of the 1970s...

The alpine jazz-rock valley has become a favorite of many Swiss musicians, among which one of the first was the Bern-based band JAZZ ROCK EXPERIENCE, formed in the very late 1960s. In 1973 in Zurich, keyboardist Kurt Baebi founded SHIVANANDA, one of the most successful live 
jazz rock bands of the time. In 1977, they released their debut instrumental LP, 'Cross Now', on Gnome Records. In 1979, the second album 'Headlines' was released. However, after the third 'Comeback' (1983), the band split up.

The development of the Alpine Prog was influenced by CIRCUS, COUNTRY LANE, IRRWISCH, KROKODIL, TEA and TOAD. From 1971 to 1978, the prog rock trio KEDAMA played quirky instrumental numbers with references to THE NICE, GENTLE GIANT, KING CRIMSON. In 1983, the instrumental fusion band PATRICK LEHMANN SEXTET recorded the curious jazz program 'Clear Sky'.

Basel-based CIRCUS has been one of the key bands in the history of Swiss Prog Rock. The quartet of vocalist, guitarist and saxophonist Roland Frei, bassist Marco Cerletti, flutist Andres Grieder and drummer and xylophonist Fritz Hauser have released just three studio albums. The self-titled debut album 'Circus', recorded in April 1976 at the Studio Harald Blobel in Bottmingen, turned out to be strong in all respects. The musicians have achieved massive polyphony using an unusual approach and without actually using keyboards. The second album of the Swiss 'Movin' On', recorded in May 1977 in Bern at the Sinus Studio, has deservedly received a cult status. Having absorbed the harmonic principles of the early VAN DER GRAAF GENERATOR, the musicians interpreted them so that the final psychedelic result looked absolutely original. With no electric guitar and organ in their arsenal, the quartet showed true wonders of ingenuity. On January 26 and 27, 1978 at the London mobile studio Maison Rouge was recorded a concert disc 'Live'. The artist is listed as CIRCUS ALL STARS BAND. This is due to the participation of a number of Swiss pop, rock and folk performers in this one-off live project. At this time, two more members joined the group, which were keyboardist / synthesizer Stephan Ammann) and trumpeter / flugelhorn player Theodor Jost. The third album 'Fearless, Tearless and Even Less', recorded at London's Trident Studios in March 1980, turned out to be the last. Andres Grieder and Theodor Jost did not take part in the work on this phonogram, and CIRCUS again found itself in the format of a quartet. The final work (possibly due to the inclusion of Hammond in the instrumental arsenal of the team) approached the territories of Jazz Rock, Psychedelic Heavy Progressive and even Space Rock ('Hearts and Spaces'). In the 1980s and 1990s, Yost worked with blues rock LAZY POKER, post-punk STITCH, funky SWISS HORNS, jazz rock PIGG-NIGG, progrock INFRA STEFF'S RED DEVIL BAND, pop-rock JUST TWO...
CIRCUS Fritz Hauser and Stefan Ammann, with the participation of Stephan Grieder, the brother of the former 'Circus' flutist Andres Grieder, continued for some time joint experimental music-making within the framework of the sympho-prog trio BLUE MOTION, creating the only multi-key instrumental album. Later, Hauser became a highly sought after musician, taking part in many Swiss projects.

In 1990, bassist Marco Cerletti recorded the jazz solo album 'Random and Providence', which turned out to be the only one. After several years of working with the LAZY POKER BLUES BAND, and then a long silence, Roland Frey reminded of himself with two albums 'Strong Is Not Enough' (2016) and 'What Happened Tomorrow' (2019), while the second includes unreleased and rare tracks, recorded between 1971 and 2016.

October 1970 is considered the starting point in the history of the eccentric group COUNTRY LANE. Then in the Swiss Chaux-de-Fonds Oliver Maire (ex-STRUCTURES), Raymond Amey (ex-LES RHINOS, NEXT TIME) and Freddy von Kaenel (ex-GOLDEN BIRDS) decided to bring to life an ambitious stage project. By the summer of 1971, Giancarlo Duella and Jean-François Donze (ex-OPEN ROAD) joined them. In this line-up, the one and a half hour Rock Opera 'The Story of Alan and Pearl' was created, which began to be performed at concerts in 1972. In June of the same year, COUNTRY LANE opened the GONG concerts in Chaux-de-Fonds and Geneva. Then the group was invited to perform at several festivals and the label 'Splendid Records' signed a contract with the musicians to record an album. 'Substratum' was released on May 16, 1973. This album featured psychedelic heavy rock on a blues basis with organ in the lead role. Critics have compared this high-profile recording to the work of URIAH HEEP, DEEP PURPLE, NEKTAR, FAIRPORT CONVENTION and SOFT MACHINE. On the second side of the LP, a conceptual work was recorded about a certain Captain Bloom, in which fragments similar to the early PROCOL HARUM and THE DOORS appeared. However, due to serious financial difficulties, the label was unable to properly 'promote' the album, which led to the collapse of COUNTRY LANE in the same 1973. In 1981, Oliver Mayr, while traveling in Greece on a motorcycle, was in an accident and died.

In January 1969, the Zurich music scene was replenished with a team with the provocatively formidable name KROKODIL. Of the five musicians included in the original line-up, more than half were not newcomers to show business. Drummer Düde Dürst has worked for THE STARLIGHTS and LES 
SAUTERELLES. Keyboardist and vocalist Hardy Hepp, recording on 'Columbia' and 'Liberty', managed to gain the fame of 'Alpine Tom Jones'. Walty Anselmo, who mastered several instruments, including the sitar, was a finalist for a local $\mathrm{R} \& \mathrm{~B}$ festival. The three were joined by Mojo Weideli on harmonica / flute / vocals, and London-born Terry Stevens on guitar / bass / vocals. Quite quickly, the Crocodiles managed to get a contract with Liberty / United Artists, and in May 1969 they went to the Munich studio Trixie, where they recorded their debut album in the style of heavy blues rock. The release was produced by German producer Siegfried E. Loch. The second disc 'Swamp' (1970) was recorded at the Munich studio 'Bavaria'. With this album, the band turned from the blues track towards acoustic-folk psychedelia. The team framework became narrow for some, and these comrades tried to realize themselves on the side. For example, drummer Durst in April 1970 at the Zurich SM Studio recorded two instrumental kraut-canvases, which formed the basis of his solo album with the characteristic name 'Krokodil Solo'. And Hardy Hepp generally threw off his 'crocodile skin' and went on free bread. The remaining musicians decided to continue their activities in four. In 1971, at Dieter Dierks' Studio, Cologne, they produced their most significant opus, An Invisible World Revealed. Among the compositions were the hypnotic folk 'Lady of Attraction' and two powerful epics with an oriental bite - 'Odyssey In Om' and 'Looking At Time'. In 1972, 'Getting Up For the Morning' was released, and the following year, the fifth 'crocodile' opus appeared - a double studio album 'Sweat and Swim' (1973), containing such zest as the 18-minute ethno-space track 'Linger'... However, after the release of this disc, the 'crocodiles' spread in different directions.

And again we are in Zurich. In 1971, Turo Paschayan (ex-LES SAUTERELLES), Roli Eggli (ex-FACT, ALASKA RANGE) and Armand Volker (ex-NEW HUE) formed a new group, which was named after the first letter of their names TEA. In 1972 in London, they were joined by a native of Malta, vocalist Marc Storace (ex-DEAF). In 1973 he made appearances on Swiss television, at the Naples Rock Festival and at the Space Electronic Club in Florence. In late 1973, keyboardist Philippe Kienholz (ex-NEW HUE, TUSK) joined the band. 1974 saw the release of the single 'Good Times/Judy' and the self-titled album Tea in the style of progressive hard rock. TEA is touring Europe with QUEEN. TEA is named 'Best Band in Switzerland' by Rohr magazine and the debut disc is an 'Album of the Year'. In 1975 the second album 'The Ship' was released. A contract is signed for the release of the band's albums in the United States. TEA is touring Europe with NAZARETH and BAKER GURVITZ ARMY. Melody Maker marks TEA as the first Swiss band to tour the UK. Keyboardist Kienholz acquires the status of 'Musician No. 2 in Switzerland'. In 1976 the third album 'Tax Exile' was released. In support of the album, a European tour is underway (Switzerland, Germany, Italy), and at the end of the year the group performs for the first time in Malta. However, the next year the band gives their last concert. Volker becomes a producer and opens his own studio in Munich. Kienholz and Pashayan are engaged in solo projects. Eggley starts his own company. Storache moved to London, where he formed the EAZY MONEY group, and in 1979 became part of KROKUS.

The creator and permanent leader of TOAD was the guitarist, keyboardist and vocalist of Italian descent Vic Vergeat, who performed in THE BLACK BIRDS in the second half of the 1960s, and the rhythm section, composed of Werni Fröhlich and Cosimo Lampis, experimented with BRIANTICKET before joining TOAD. The fourth member was free vocalist Benj Jaeger. From 1971 to 1975, three great hard-to-write albums were released. In 1978, under the changed name VIC VEA BAND with the album 'Toad', they ended their career in rock. Cosimo Lampis, after TOAD's disbandment, drummed for SUTER BLINDDATE, which recorded their only hard rock album, 'First Rendez-Vous' (1981). This veteran rock group (the rest were young, obscure musicians) included John Woolloff, who had a background in the progressive heavy psychedelic band SPOT in the early 1970s. In the mid-1980s, TOAD's Vic Vergeat played in the synth-pop band THE BANK.

In 1974 in Solothurn, former KAKTUS members - vocalist, bassist and percussionist Chris von Rohr (in 1967 he created his first band, which constantly changed names - THE SCOUTS, TEARS OF LOVE, IN, INDIAN SUMMER) and guitarist Tommy Kiefer was the now well-known KROKUS group was created. Although the name is formally derived from the crocus flower, the band members chose it due to the fact that there is 'Rock' in the middle of the word KROKUS. In 1979, ex-TEA and EAZY MONEY vocalist Marc Storace joined the group, with whom the album 'Metal Rendez-vous' (1980) was recorded, which led to international recognition and major success in Europe and the United States. In 1981, KROKUS was joined by guitarist Armand Meyer, whose rock biography includes pages related to COBRA, STEALIN' HORSES, KATMANDU, GOTTHARD and ASIA. The most successful KROKUS album is considered 'Headhunter' (1983)... In 1987, Mark Storace of KROKUS co-produced 
the debut album of the AOR band CHINA. In 1991, with the participation of Vic Vergeat (ex-TOAD), he created the one-album soft-rock project BLUE, characterized by bright and catchy melodies. Many vulgarly call KROKUS a kind of Swiss modification of the AC/DC. Of course, such a simplification is unfair - the group has a tangible amount of individuality, but undoubtedly, a certain influence of the crushing Australian heavy giants is felt. Many KROKUS releases have been successful, including all the relatively new works - 'Hellraiser' (2006), 'Hoodoo' (2010), 'Dirty Dynamite' (2013) and 'Big Rocks' (2017). In the summer of 2021, KROKUS are planning to complete their farewell tour. On January 13, 2019, after the release of KAKTUS with the symbolic name 'Back to the Future 1969-2018', their founder, Duco Aeschbach, died.

The soul funk line is at the forefront of the SWISS HORNS albums 'Peace Again' (1980) and 'Second Sight' (1981). In the mid-70s and early 80s, a lighter pop version of rock was offered by CHICKEN FISCHER, SHIFTER, RACE and THE LOONEY TUNES. And bands like TNT, KLEENEX, NASAL BOYS, TECHNYCOLOR, SPERMA, CRAZY, EXPO and THE TICKETS remained stoically loyal to the punk rock cause [Lurker Grand, 2006].

Since 1978, energetic synth pop music has been played by Dieter Meier and Boris Blank, known as the YELLO duo. Their style has had a fundamental impact on club aesthetics. The newest album 'Point' was released on August 28, 2020. The 14th release has arrived from an alternate universe and, codifying its Dada formula, sounds in the best traditions of this pair of sound wizards. Meyer's vocals have always been based on eerie inhumanity - electronic processing made him like a hellish robot, thus emphasizing their connection with the Cosmos! The disc has a chance to become the best album of the year in its category.

A special place was taken by the 'fish-like' CLEPSYDRA, which in 30 years have released five Neoprog-albums - from 'Hologram' (1991) to 'The Gap' (2019).

In the 1980s, PAGANINI took the 'heavy road'. This group was founded in 1983 by vocalist Marco Paganini and guitarist Ralph Murthy, who by that time had played for several years in the Hanoverian VIVA and recorded a couple of albums with them. In 1984, the new group signed to Vertigo Records and the following year released their debut, 'Weapon of Love'. The next album 'It's A Long Way to the Top' (1987) took the sixth place in the Swiss charts and turned out to be the best in their discography. However, Murti left the group just at this time. Subsequently, PAGANINI recorded four more studio albums in the melodic heavy style and the compilation 'Resurrection' (2005) with their reworked best pieces. Unfortunately, both founders of this Swiss Hard Rock band are no longer alive: Ralph Murthy died in September 2013, and Mark Paganini passed away in January 2019...

In 1990, under the influence of PINK FLOYD's ideas, vocalist and drummer Reto Iseli formed GLACIER EAGLES. At the end of 1993, the band reformed into COSMOS. 'The Deciding Moments of Your Life' (1994) was warmly received and the band achieved success in their home country thanks to their outstanding live performances. COSMOS disbanded in 1998, but was revived in 2004.

In 1992, vocalist Steve Lee and guitarist Leo Leoni, both starting out in FORSALE, founded GOTTHARD with influences from LED ZEPPELIN, AC / DC, WHITESNAKE, DEEP PURPLE... On October 5, 2010, Lee died in a car accident. The new singer was Nic Maeder and he recorded 'Firebirth', 'Bang!', 'Silver' and '№13'. The band managed to keep the traditional sound. On October 2, 2020, GOTTHARD released Steve Lee's 10th anniversary album. 'Steve Lee - The Eyes Of A Tiger' has a new accompaniment to the vocalist's latest studio tracks.

In the 1990s, CHERRY PIE (Heavy Rock), GALAAD (Eclectic Prog), SATROX (Melodic Hardn-Heavy), SULTAN, SUN'N'STEEL (Metal) and XPRESS (Melodic Hard Rock) stood out... By the way, years later in 2019, the SUN'N'STEEL and GALAAD groups each released a new (the third in a row in their careers) album, and the power metal team CRYSTAL BALL, created on the basis of CHERRY PIE, presented its tenth the release is the energetic and judas-priestly 'Crystallizer', recorded with the participation of guitarist Tony Castell (ex-KROKUS). In 2019, CRYSTAL BALL celebrated its 20th anniversary with a double album, '2020', which includes 20 reworked (in whole or in part) tracks. Recreated with the support of HELLOWEEN's Dani Löble, the BLACK ANGELS legend (disbanded in the mid-80s) has given out the downhole 'Steamroller'. And such as THE FLYING MARS, vibrating for genre formalities, are carried away to distant cosmic worlds...

The 1980s saw notable Hard Rock band SERGEANT from Vurenlos, Zurich thrashers CORONER, MESSIAH from Baare and nicknamed 'Rush of Thrash Metal' in honor of the legendary Canadians. Since 1987, the hard rock group GENOCIDE has been active, whose members later worked with KROKUS, CRAZY SWEEPER and ALMØST HUMAN, and the group, after recording 4 releases in 1997, was reformatted into the bluesrock unit SIDEBURN. Roland Pierrehumbert was the founder of GENOCIDE, SIDEBURN and BLUE 
MOJO. On April 3, 2020, Roland released 'Snakes and Repents' with his new team RAWLAND. This cult vocalist and author of this interstyle mature work wrote wishes for the readers, expressing hope for performances in front of the Ukrainian audience... [Synieokyi O., 2021].

Now let's summarize the main results. Rock musicregardless of its provenance - is now an everyday companion and especially popular with those who otherwise insist on their national identity [Stefan Künzli, 2021]. The Swiss school of rock music has given the world musical culture a lot of achievements, the main of which we have described above. French (along with German, Italian and Romansh) is one of the official languages of Switzerland. And although every inhabitant of this country of mountains, cuckoo clocks and exact time can safely speak any of these languages anywhere, and soon Switzerland will most likely become Franco-German, the Swiss sing Rock mostly in English. This is mainly due to the special kind of culture of this alpine country called 'Music for Export'. Therefore, critics began to separate 'Culture from Switzerland' from 'Swiss culture', the hallmark of the second are folk orchestras with alpenhorns...

\section{BIBLIOGRAPHY}

1. Grand L. Die Not hat ein Ende: The Swiss Art of Rock. Publishen: ¡Edition Patrick Frey, 2015. 500 p.

2. Grand L. Hot Love - Swiss Punk Wave 1976-1980. Publisher: Softcover, 2006. 324 p.

3. Künzli S. «Swiss Rock Pioneers: A Search for Traces in the Rebellious Founding Years. Published by Zytglogge, $2021.350 \mathrm{p}$.

4. Synieokyi O. V. Cosmophony 2112. Publisher: Rock-Ex-Press, 2021. 980 p.

5. Synieokyi O. V. Some Reflections On The Past, Present and Future of Space Rock Music/ SENTENTIA. European Journal of Humanities and Social Sciences. 2021. № 3. P. 63-83.

6. Synieokyi O. V. The study of sessional recordings of 1962-1972 from the BBC radioarchive (The Beatles, Pink Floyd, Deep Purple) Visnik Kharkivs'koï derzhavnoï akademiï kul'turi. 2021. № 59. C. 19-32.

7. Synieokyi O. V. Viruses That Continue To Kill Rock (Why Are Legal Remedies No Longer Effective?) Naukovij chasopis Nacional'nogo pedagogichnogo universitetu imeni M. P. Dragomanova. Seriya 18. Vip. 35. 2021. C. 50-55.

\section{REFERENCES}

1. Grand L. Die Not hat ein Ende: The Swiss Art of Rock. Publisherf: ¡Edition Patrick Frey, 2015. 500 p.

2. Grand L. Hot Love - Swiss Punk Wave 1976-1980. Publisher: Softcover, 2006. 324 p.

3. Künzli S. «Swiss Rock Pioneers: A Search for Traces in the Rebellious Founding Years. Published by Zytglogge, 2021. 350 p.

4. Synieokyi O. V. Cosmophony 2112. Publisher: Rock-Ex-Press, 2021. 980 p.

5. Synieokyi O. V. Some Reflections On The Past, Present and Future of Space Rock Music/ SENTENTIA. European Journal of Humanities and Social Sciences. 2021. № 3. P. 63-83.

6. Synieokyi O. V. The study of sessional recordings of 1962-1972 from the BBC radioarchive (The Beatles, Pink Floyd, Deep Purple) Visnik Kharkivs'koï derzhavnoï akademiï kul'turi. 2021. № 59. C. 19-32.

7. Synieokyi O. V. Viruses That Continue To Kill Rock (Why Are Legal Remedies No Longer Effective?) Naukovij chasopis Nacional'nogo pedagogichnogo universitetu imeni M. P. Dragomanova. Seriya 18. Vip. 35. 2021. C. $50-55$. 